\title{
TREE-RING CHRONOLOGY AS A SOURCE OF INFORMATION ON SUSCEPTIBILITY OF SITKA SPRUCE TO CLIMATIC CONDITIONS OF POMERANIA (NORTHERN POLAND)
}

\author{
EDWARD FELIKSIK and SŁAWOMIR WILCZYŃSKI \\ Agricultural University of Cracow \\ Department of Forest Protection and Forest Climatology, \\ Al. 29 Listopada 46, 31-425 Cracow, Poland
}

\begin{abstract}
This paper presents results concerning climatic conditions affecting diameter growth of Sitka spruce introduced to Baltic Pomerania (Sławno Forest District). A relatively high homogeneity of tree-ring series permitted to construct on their basis the tree-ring chronology of Sitka spruce. A significant positive correlation was found between radial increments of Sitka spruce and air temperatures of winter and spring months (January-April) and a negative relationship between radial increments and temperature of May. This study also showed a distinctly positive correlation between diameter growth and precipitation in July and November of the previous year, and precipitation in February and in summer season (June-August) of the current year. During years with low precipitation in summer or low temperatures in winter and spring all trees produced narrow tree-rings. The proportion of air temperature and precipitation in variation of radial increment of Sitka spruce, expressed by the coefficient of multiple determination, was $52 \%$.
\end{abstract}

Keywords: Picea sitchensis, Sitka spruce, dendrochronology, dendroclimatology, ring-width, treering chronology.

\section{INTRODUCTION}

Sitka spruce (Picea sitchensis (Bong.) Carr) is a native tree of the western part of North America. It occurs in a narrow belt running along the Pacific coast from Alaska to California. In British Columbia, Sitka spruce grows as far as about $200 \mathrm{~km}$ inland. In the mountains, it occurs up to $900 \mathrm{~m}$ above the sea level (Harlow et al., 1978). Sitka spruce is a fast growing species of high productivity (Bugała, 2000).

In European forestry in the middle of the $19^{\text {th }}$ century there was an extensive program of introduction of fast growing tree species. Sitka spruce was also among species planted in numerous experimental plantations. Thanks to the efforts of German and Austrian foresters Schwappach, Wiedemann and Cieslar some plantations exist until the present time, also within present boundaries of Poland (Bellon et al., 1977). The stand situated in the Sławno Forest District is one of the best (Fig. 1).

Corresponding author: S. Wilczyński

e-mail: rlwilczy@cyf-kr.edu.pl

ISSN 1897-1695 (online), 1733-8387 (print) (C) 2008 GADAM Centre, Institute of Physics, Silesian University of Technology.

All rights reserved.
Trees in this stand, over 100 years of age, make a good material for dendroclimatological investigations. During such a long period of time their susceptibility to weather conditions of this region has been registered in their annual rings.

Thus the dendroclimatological analysis will permit to estimate the effect of climatic conditions on efficiency of metabolic processes responsible for growth.

The aim of this study was to construct a tree-ring chronology of Sitka spruce population, and to try, on the basis of this chronology, to estimate the effect of two main meteorological elements, i.e. air temperature and precipitation, on the size of radial increments of this tree species. It was attempted in this way to estimate the susceptibility of this introduced species to climatic conditions of the Baltic coast.

Hitherto no dendroclimatic investigations on Sitka spruce were carried out in Poland. Due to its fast growth and high wood quality it could become a valuable tree species in Polish forests. 


\section{MATERIAL AND METHODS}

The forest stand was situated in the Stary Kraków forest section of the Sławno Forest District in compartment 85 (Fig. 1). Sitka spruce trees were growing on an area of about one hectare in size. The site was classified as a moderately fresh mixed broadleaved forest site with acid brown soil formed from sand of medium size. In that stand Sitka spruce occurred in a group mixture with Scots pine and European beech. It reached $37 \mathrm{~m}$ in height and $68 \mathrm{~cm}$ in diameter at breast height on the average.

Dominant and undamaged trees are the most useful for studies of climat-tree growth relationships. Their growth was regulated by the complex of biosocial conditions relatively stable in time. For this study 25 such trees were selected. Their trunks were cored with the Pressler increment borer on their southern side, $1.3 \mathrm{~m}$ above the ground level. This is the trunk zone where the climatic signal registered in tree-rings is most strongly revealed and easy to be cored (Mäkinen and Vanninen, 1999). Tree-ring width was measured on the cores. Measurement series of each tree were verified to detect possible errors. The computer program COFECHA (Holmes, 1986) was used. This procedure yielded 22 correctly dated tree-ring series (Fig. 2). On their basis, a chronology was created, which is a time series of mean tree-ring widths. Individual tree-ring series were standardized using the computer program ARSTAN (Cook and Holmes, 1986). On the basis of indexed series a residual chronology was elaborated.

To analyze the influence of climatic conditions on tree radial increment a method of similarity based on the coefficient of convergence GL (Gleichläufigkeit) (Huber, 1943; Eckstein and Bauch, 1969), a method of correlation function and multiple regression (response function) were used (Fritts et al., 1971; Fritts, 1976 and Guiot et al.,

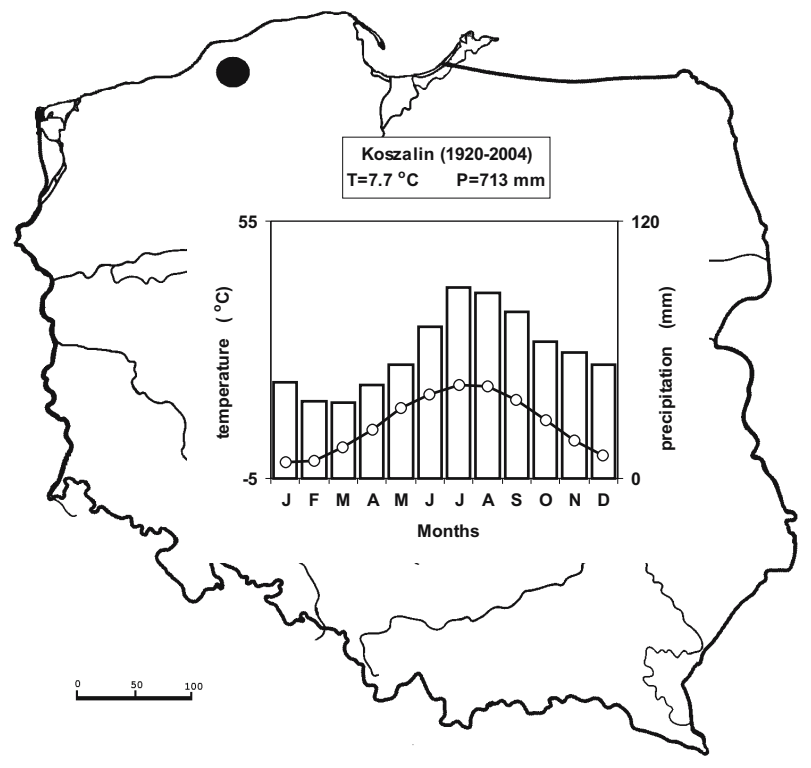

Fig. 1. The map of Poland with location of study areas (black dot). The climatic diagram for the meteorological station in Koszalin: line - mean monthly air temperature, bars - total monthly precipitation; $T$ - mean annual temperature, $P$ - total annual precipitation.
1982). For this purpose computer program RESPO (Holmes and Lough, 1999) was used. Indexes of residual chronology were the dependent variables, while mean monthly values of air temperature and mean monthly values of total precipitation for the period 1920-2004 were the independent variables. In computations, the period from July of the previous year to September of the current year, i.e. the year when the tree-ring was produced, was taken into account. Also the method of signature years was used in analyses (Kelly et al., 1989; Spain and Pilcher, 1994). In this study it was assumed that the positive signature year is a year in which at least $90 \%$ of trees increased the tree-ring width in comparison with the previous year, while the negative signature year is a year in which at least $90 \%$ of trees decreased the tree-ring width in comparison with the previous year. Subsequently, the climatic conditions prevailing in these years were analyzed to discover the reasons for the occurrence of signature years.

Climatic data were obtained from the meteorological station - Koszalin of the Institute of Meteorology and Water Management.

\section{RESULTS}

Indexing of 22 tree-ring series caused that the trend and long-term fluctuations were eliminated (Fig. 2). In consequence, a short-term variation, mainly determined by the meteorological factor, was exposed in residual chronology. This was shown by a higher value of the mean coefficient of sensitivity.

This chronology was also characterized by a very low autocorrelation of the $1^{\text {st }}$ order and a lower variation of index values (Table 1).
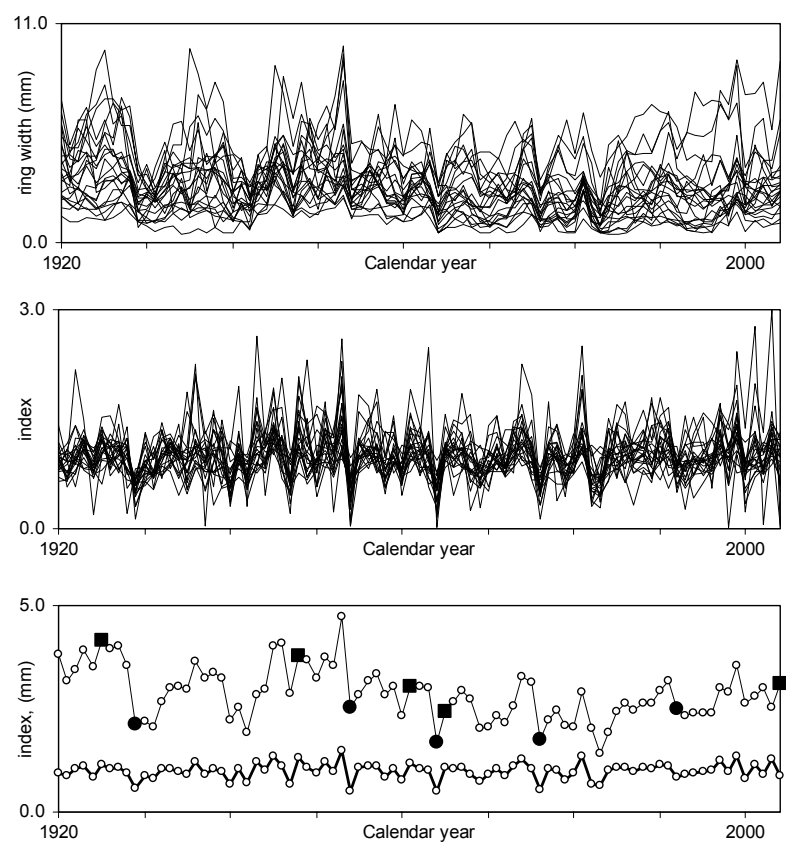

Fig. 2. Tree-ring series of 22 Sitka spruce trees (upper figure); 22 indexed series (middle figure); site tree-ring chronology - thin line, and site residual chronology - thick line (lower figure). Positive signature years - black squares, negative signature years - black circles. 
Table 1. Selected statistics of ring-width and residual chronology of Sitka spruce.

\begin{tabular}{|c|c|c|c|c|c|c|c|}
\hline Chronology & Interval & Mean & $\begin{array}{l}\text { Mean sensi- } \\
\text { tivity }\end{array}$ & $\begin{array}{c}\text { Standard devia- } \\
\text { tion }\end{array}$ & $\begin{array}{c}\text { Coefficient of } \\
\text { variation }\end{array}$ & $\begin{array}{l}\text { Autocorrela- } \\
\text { tion 1-order }\end{array}$ & AR - model \\
\hline Ring-width & $1921-2004$ & 2.85 & 0.161 & 0.640 & $22.4 \%$ & 0.562 & $\bar{x}$ \\
\hline Residual & $1921-2004$ & 1.00 & 0.223 & 0.182 & $18.2 \%$ & -0.145 & (1) \\
\hline
\end{tabular}

The following relationships were found for the period 1920-2004: a statistically significant positive relationship between the value of radial increment and the mean temperature of winter and spring months (January-April), and a negative relationship between the increment and the mean temperature of May as well as the mean temperatures of July and November of the previous year (Fig. 3).

A significant positive effect on value of increment had moisture delivered to soil by precipitation occurring in July and November of the previous year and also in February and during summer months (June-August) of the current year (Fig. 3).

The proportion of temperature and precipitation in variation of radial increment of Sitka spruce, expressed by the coefficient of multiple determination, was $52 \%$, and the proportion of air temperature $\left(\mathrm{R}^{2}=33 \%\right)$ was higher than that of precipitation $\left(\mathrm{R}^{2}=21 \%\right)$.

A strong effect of air temperature occurring on the turn of winter on the radial increment produced by Sitka spruce during the following growing season was confirmed by a comparison between the residual chronology and the mean temperature curves for the period FebruaryMarch (Fig. 4). These curves were characterized by a highly significant coefficient of convergence $\mathrm{GL}=77.4 \%$ $(P<0.001)$.

The response of trees to environmental factors are reflected by signature years. Between 1920 and 2004 there were 10 such years, including 5 positive and 5 negative years (Fig. 5). These years comprised only $12 \%$ of the total number of years of this period. Such a uniform reaction of trees may be caused by the environmental factor of a particularly high intensity.

The results of analyses permitted to conclude that thermal conditions and possibly pluvial conditions of the current year or the previous year could have been such factors for Sitka spruce. The climatic diagrams showing mean monthly values of air temperature and precipitation

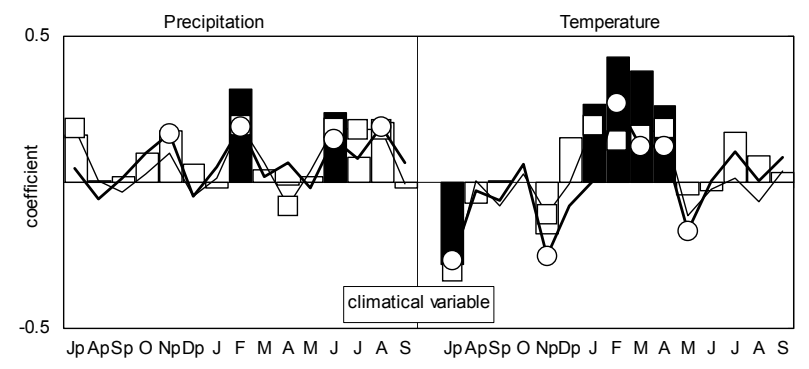

Fig. 3. Results of correlation and response function. Correlation coefficients - bars; regression coefficients computed separately for temperature and precipitation - thin line, regression coefficients computed taking into account temperature and precipitation - thick line. Significant coefficients at the 95\% confidence level - black bars and white squares and circles. of positive and negative signature years have confirmed the above conclusion (Fig. 6).

It turned out that temperatures of winter and spring months during positive signature years were much higher than during negative signature years. Also positive signature years were characterized by higher precipitation, especially in February and during the summer season (Fig. 6).

\section{DISCUSSION}

Sitka spruce on the west coast of North America grows in a mild and moist oceanic climate characterized

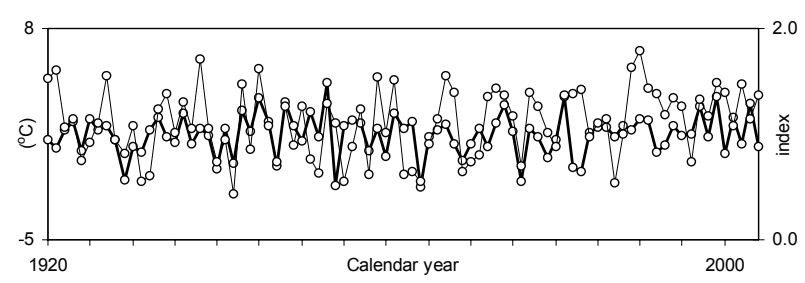

Fig. 4. Residual chronology (thick line) and mean temperature of the February-March period of the current year (thin line).

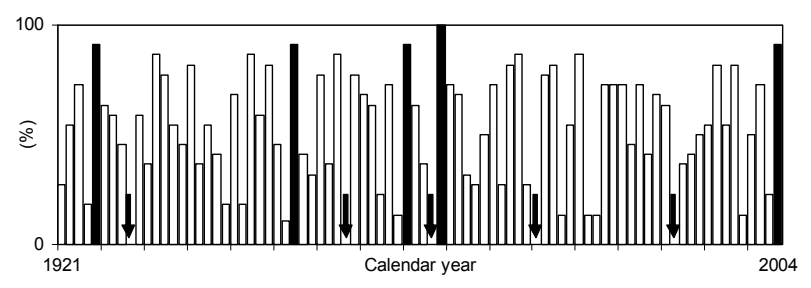

Fig. 5. Percentage of trees increasing tree-ring width. Positive signature years - black bars; negative signature years - arrows.
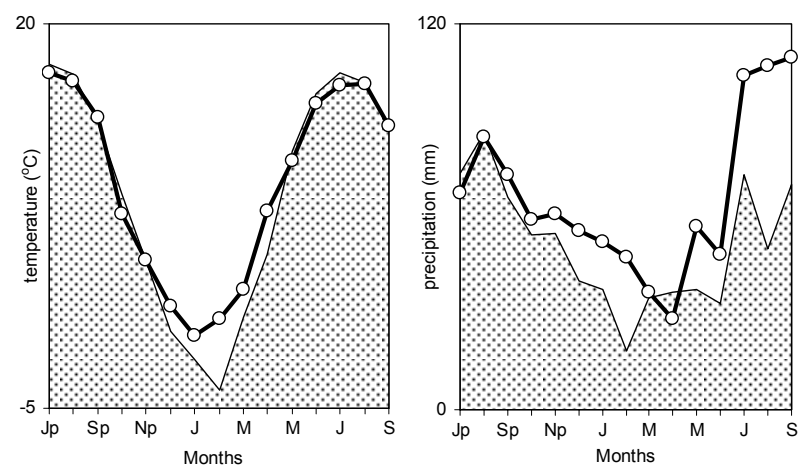

Fig. 6. Climatic diagrams of signature years. Mean monthly air temperature and mean monthly total precipitation of positive signature years - lines, and negative signature years - dotted area. Jp - July of the previous year, $S$-September of the current year. 
by a very high precipitation during the growing season. There, it grows in river valleys and on mountain slopes declining towards the coast (Harlow et al., 1978). When introduced to Europe in the middle of the $19^{\text {th }}$ century it found the most favorable conditions of growth under oceanic climate of British Isles. While in continental Europe it is being damaged by winter frosts, and it also suffers from summer draughts (Bugała, 2000).

Our studies showed that mainly winter frosts and dry weather in summer are the factors limiting the radial increment of Sitka spruce. This has confirmed observations made by foresters (Bellon et al., 1977; Bugała, 2000). A growing season, shortened by winter cools occurring until late spring, as well as frosts injuring the living tissues, caused lower annual diameter increments of trees of this species. The later beginning of the growing season slowed down the rate and efficiency of tree physiological processes taking place in spring. This study also showed high moisture requirements of Sitka spruce. It turned out that the increased radial increment of Sitka spruce trees growing in Pomerania depended not only on high precipitation during the growing season but also on moisture delivered to the soil during the previous year (in July and November) and moisture stored in the soil just before the growing season, i.e. thanks to precipitation in February.

The results of this study permit to form the opinion that under climate of the Baltic Forest Region (Trampler et al., 1990) in Poland the Sitka spruce has found favorable conditions for its growth. In the study area, representing the fresh broadleaved forest site type, its diameter and height increments are higher than those of native tree species, such as Norway spruce, Scots pine or European fir, growing in the same site. Summer precipitation (JuneAugust) on the Baltic coast is quite high, reaching $250 \mathrm{~mm}$ on the average. Winter temperatures in that region are relatively high. The mean temperature of the coldest month, i.e. January, is $-1.0^{\circ} \mathrm{C}$. Genetically conditioned requirements of Sitka spruce correspond with a relatively mild climate of the sea cost. For this reason Sitka spruce could be more widely used in forestry of Pomerania.

\section{CONCLUSIONS}

Sitka spruce showed a relatively high homogeneity of diameter increment. This permitted to construct the ringwidth chronology of relatively high quality and sensitivity. These characteristics showed the sensitivity of this foreign tree species to relatively mild climatic conditions of the Baltic cost.

The 1980s and 1990s were the years which weakened the climatic signal contained in tree-rings. An increased heterogeneity of increment behavior of studied trees was observed during that period of time. It was probably connected with a high level of air pollution.

The results showed that Sitka spruce found in the Baltic Forest Region of Poland satisfactory climatic condi- tions for its growth. Its high sensitivity to long and frosty winter and precipitation deficit in summer, observed during specific years, is softened by relatively warm and moist climate of Pomerania.

Generally favorable distribution of precipitation, culminating there during the summer, and most often mild and short winters, create favorable conditions for normal development and growth of Sitka spruce. In our opinion this species should find a greater acceptance in forestry of Baltic Region.

\section{REFERENCES}

Bellon S, Tumiłowicz J and Król S, 1977. Obce gatunki drzew w gospodarstwie leśnym (Foreign tree species in forestry). Warszawa, Państwowe Wydawnictwo Rolnicze i Leśne: 267 pp (in Polish).

Bugała W, 2000. Drzewa $i$ krzewy (Trees and shrubs). Warszawa, Państwowe Wydawnictwo Rolnicze i Leśne: 614 pp (in Polish).

Cook ER and Holmes RL, 1986. Users manual for program Arstan. In: Holmes RL, Adams RK and Fritts HC, eds., Tree-ring chronologies of western North America: California, eastern Oregon and northern Great Basin. Tucson, Laboratory of Tree-Ring Research, University of Arizona. Chronology Series 6: 50-65.

Eckstein D and Bauch J, 1969. Beitrag zur Rationalisirung eines dendrochronologischen Verfarens und zur Analyse seiner Aussagesicherheit (Contribution to the rationalization of a dendrochronological procedure to the analysis of confidence). Forstwissenschaftliches Centralbatt 88(4): 230-250 (in German).

Fritts HC, Blasing TJ, Hayden BP and Kutzbach JE, 1971. Multivariate techniques for specifying tree-growth and climate relationships and for reconstructing anomalies in paleoclimate. Journal of Applied Meteorology 10(5): 845-864, DOI 10.1175/15200450(1971)010<0845:MTFSTG $>2.0 . \mathrm{CO} ; 2$.

Fritts HC, 1976. Tree-Rings and Climate. New York, London, San Francisco, Academic Press: 567 pp.

Guiot J, Berger AL, Munaut AV and Till C, 1982. Response functions. In: Hughes MK, Kelly PM, Pilcher JR and LaMarche VC, eds., Climate from tree rings. Cambridge, Cambridge University Press: 38-45.

Harlow WM, Harrar ES and White FM, 1978. Texbook of Dendrology. Covering the Important Forest Trees of the United States and Canada. New York, McGraw-Hill Book Company: 134-136.

Holmes RL, 1986. Quality control of crossdating and measuring. Users manual for computer program COFECHA. In: Holmes RL, Adams RK and Fritts HC, eds., Tree-rings chronologies of western North America: California, eastern Oregon and northern Great Basin. Tucson, Laboratory of Tree-Ring Research, University of Arizona. Chronology Series 6: 41-49.

Holmes RL and Lough JM, 1999. Users manual for program RESPO. Tucson, Laboratory of Tree-Ring Research, University of Arizona.

Huber B, 1943. Über die Sicherheit jahrringchronologischer Datierung (About the confidence of tree-ring dating). Holz als Roh-und Werkstoff 36: 263-268 (in German).

Kelly PM, Murno MAR, Hughes MK and Goodess CM, 1989. Climate and signature years in west European oaks. Nature 340(6228): 5760, DOI 10.1038/340057a0.

Mäkinen H and Vanninen P, 1999. Effect of sample selection on the environmental signal derived from tree-ring series. Forest Ecology and Management 113(1): 83-89, DOI 10.1016/S03781127(98)00416-2.

Spain J and Pilcher JR, 1994. Signature years in European oak chronologies A.D. 1600-1750 and possible climatic causes. In: Frenzel B, ed., Climatic trends and anomalies in Europe 1675-1715. Paleoclimate Research 13: 123-131.

Trampler T, Kliczkowska A, Dmyterko E, Sierpińska A, 1990. Regionalizacja przyrodniczo-leśna Polski na podstawach ekologiczno - fizjograficznych (The nature-forest regionalisation of Polnad on the ecological and physiographical grounds). Warszawa, Państwowe Wydawnictwo Rolnicze i Leśne: 159 pp (in Polish). 